\title{
口腔がん術後感染症とその予防
}

\author{
梅田 正 博 $^{1)}$ ・船原まどか ${ }^{1)}$ \\ 林田咲 ${ }^{1)} \cdot$ 五月女さき子 ${ }^{2)}$

\section{Postoperative infection after oral cancer surgery and its prophylaxis}

\author{
UMEDA Masahiro $^{1)} \cdot$ FUNAHARA Madoka $^{11}$ \\ HAYASHIDA Saki $^{1)} \cdot$ SOUTOME Sakiko $^{2)}$
}

\begin{abstract}
We described postoperative infection after oral cancer surgery and its general prophylaxis, and showed our study about preventive effects of perioperative oral management on postoperative infection. The frequency of surgical site infection (SSI) after oral cancer surgery is high, especially in clean-contaminated surgery or major surgery. To prevent SSI, general prophylaxis recommended by CDC Guideline should be performed.

The number of oral bacteria increases remarkably in patients during intubation by trachectomy. We reported that topical administration of tetracycline ointment in the oral cavity reduced bacteria in the oropharyngeal fluid to the fewer level than that before intubation during 6 hours. A multicenter randomized clinical trial on the preventive effect of topical tetracycline administration on SSI is being performed now.

Postoperative pneumonia sometimes occurred in oral cancer surgery. The risk factors for development of postoperative pneumonia are old age, diabetes, lower pulmonary function, smoking, large surgical stress, postoperative dysphagia, etc. However, few investigators reported the relationship between oral hygiene and pneumonia. We reported that perioperative oral management reduced the risk of postoperative pneumonia in patients undergoing esophageal cancer surgery in a multicenter retrospective study. These results suggest that proper oral managements may prevent the development of postoperative pneumonia also in oral cancer surgery.
\end{abstract}

Key words: postoperative infection (術後感染), oral cancer surgery (口腔がん手術), surgical site infection（手術部位 感染), postoperative pneumonia (術後肺炎), perioperative oral management (周術期口腔管理)

\section{I. 緒言}

口腔がん手術では手術後に手術部位感染 (Surgical Site Infection: 以下 SSI) や肺炎などの遠隔感染 (Remote Infec-

1) 長崎大学大学院医柬薬学総合研究科口腔腫瘍治療学分野 (主任：梅田正博教授)

2) 長崎大学病院周術期口腔管理センター (主任：梅田正博教授)

${ }^{1)}$ Department of Clinical Oral Oncology, Nagasaki University Graduate School of Biomedical Sciences (Chief: Prof. UMEDA Masahiro)

${ }^{2)}$ Perioperative Oral Management Center, Nagasaki University Hospital (Chief: Prof. UMEDA Masahiro) tion: 以下 RI）を生じることがしばしばある。とくに原発巣 と頸部との一塊切除や, 皮弁による再建手術を伴う場合, 術後一定期間気管切開下で管理される場合などに術後感染 は生じやすい. 口腔がん手術で術後感染の頻度が高い理由 としては, 術前より低栄養状態となりやすいこと, 手術侵 襲が大きいこと, 顎口腔領域は解剖学的に複雑な構造をし ており死腔を生じやすいことなどさまざまな要因がある が，とくに大きな理由として病原性微生物を含んだ唾液や 口腔内眝留液に創部がさらされることと, 術後嚥下障害を きたすと口腔の自浄作用が損なわれ病原性微生物が著明に 増加すること, 污染された口腔咽頭貯留液を誤嚥しやすい ことなどが考えられる。 
術後感染の予防は抗菌薬の全身投与が中心であることは 言うまでもないが, 点滴静注された抗菌薬は口腔がん術後 患者の口腔咽頭貯留液中にはほとんど移行していないこと をわれわれは確認している。したがって抗菌薬全身投与の みでは術後感染を完全に予防することは困難であると推察 される。 2012 年に周術期口腔機能管理が診療報酬に導入 された。口腔管理により SSI や術後肺炎を予防しようとす る報告も散見されるが，エビデンスのある論文はないのが 現状である。本稿では術後感染に関する CDC ガイドライ ンを中心とした感染予防対策について概説するとともに， 口腔管理によりはたして術後感染の発症頻度を抑制するこ とができるかどうか，できるとしたらどのような口腔管理 方法が適切かについて, 当科で行っている基礎的臨床的研 究の結果も踏まえて紹介する.

\section{II. 術後感染の一般的予防法}

術後感染症はSSI と RI に大別される（表 1). SSI はさら に表層 SSI, 深部 SSI, 臓器体腔 SSI の 3 者に分けられるが, 口腔がんの場合は臓器体腔 SSI は存在せず, 表層 SSI と深 部 SSIの両者に分類される。また, RI としては呼吸器感染 のほかに, 尿路感染, カテーテル感染, 薬剤関連性腸炎な どもあるが, 本稿ではSSI 打よび呼吸器感染としての術後 肺炎について，その現状や予防法について考えることとす る.

CDC Guideline for Prevention of Surgical Site Infection $1999^{1}$ ) では, 外科手術の創部は Class I : Clean (清潔), Class II : Clean-Contaminated (準污染), Class III : Contaminated (污染), Class IV：Dirty（感染）の 4 種類に分類されるが, 多くの口腔がん手術は Class II の準污染に該当する。この ように口腔がん手術では污染された口腔内貯留液に創部が 常時さらされることを知っておく必要がある.

一般に外科手術全般の SSI のリスク因子についてはさま ざまな患者因子, 手術因子が明らかとなっている（表 2). これらはほとんどが口腔がん手術にもあてはまるので注意 を要する。たとえば，口腔がん患者は術前には低栄養状態 となっていることが多く術前の栄養状態を改善しておくこ と, 手術直前の剃毛は避けること, 術前入院期間は可及的 に短くすること，術中には止血を十分に行い死腔を作らな いようにすること，適切な抗菌薬予防投与を行うことなど が SSI 予防のために必要である.

創が口腔と頸部に及ぶような侵襲の大きな口腔がん手術 に打けるSSI の起炎菌としては, 黄色ブドウ球菌, 口腔レン サ球菌，あるいはペプトストレプトコッカスなどの口腔嫌気 性菌が挙げられる ${ }^{1)}$ ， 口腔がん手術時に使用される予防的 抗菌薬として，口腔を開放しないClass I の手術（頸部郭清
表 1 SSI の診断基準

1. 表層 SSI

手術後 30 日以内に起こった感染で，切開部の皮膚ま たは皮下組織のみであり，少なくとも以下の 1 つが認 められる。

1 ）切開部の表面から検査上の確診の有無を問わず排膿 がある.

2 ）切開創の表層から無菌的に採取された液体または組 織の培養から病原菌が分離される。

3 ) 以下の感染の症状や徴候のうち少なくとも 1 つがあ る.

疼痛または圧痛

限局性の腫脹

発赤, 熱感

外科医が意困的に皮膚浅層の縫合を開けた場合 （切開部の培養が陰性の場合を除く）

4 ）外科医または主治医が浅部切開部位SSI と診断した。 *以下の状態はSSI とはしない.

1）縫合糸膿瘍（縫合糸の穿通した穴に限局した最小 単位の炎症または浸出）

2 ）会陰切開部や新生児の包皮切開層の感染

3 ）熱傷の感染

4 ）筋膜や筋層に波及した切開部 SSI (深部 SSI 参照)

注：感染した会陰切開, 環状切開部および熱傷には 別の特別な基準がある

2 . 深部 SSI

人工物の埋めこみが行われなかった場合には術後 30 日以内、移植人工物が残された場合には術後 1 年以内 に手術に関連して感染が起こり，さらに手術切開部位 の深部組織 (たとえば筋膜や筋層) を含む。さらに以 下のうちの少なくとも 1 つが認められる.

1) 手術部位の器官・体腔からではなく，切開深部から の排膿。

2 ）次の感染の症状や徴候の少なくとも 1 つがあり深部 切開創が自然に離開したか, 外科医が創を意困的に 開放した場合 (切開創の培養が陰性の場合を除く). $38^{\circ} \mathrm{C}$ 以上の発熱 限局した疼痛

圧痛.

3 ）深部切開創の膿瘍やほかの感染の証拠が直接的に, あるいは再手術時に，あるいは組織病理学または画 像検査で発見される。

4 ）外科医または主治医が深部 SSI と診断した.

注：(1)浅部深部両方に感染が及ぶ場合は深部 SSI として 報告.

(2)切開創からドレーンされる臟器・体腔 SSI は深部 SSI として報告.

3. 臓器体腔 SSI

略 
表 2 SSI 発症のリスクとなりうる患者因子打よび手術因子

\begin{tabular}{|c|c|}
\hline 患者因子 & $\begin{array}{l}\text { 年 齢 } \\
\text { 栄養状態 } \\
\text { 糖尿病 } \\
\text { 喫 煙 } \\
\text { 肥 満 } \\
\text { 離れた体の部位に感染が存在 } \\
\text { 微生物の保菌 } \\
\text { 免疫反応の変化 } \\
\text { 術前入院期間 }\end{array}$ \\
\hline 手術因子 & $\begin{array}{l}\text { 手術時手洗いの長さ } \\
\text { 皮膚消毒 } \\
\text { 術前剃毛 } \\
\text { 術前皮膚処置 } \\
\text { 手術時間 } \\
\text { 抗菌薬予防投与 } \\
\text { 手術室の換気 } \\
\text { 器具の不十分な滅菌 } \\
\text { 手術部位の異物 } \\
\text { ドレーン } \\
\text { 手術手技 } \\
\quad \text { 止血不十分 } \\
\text { 死腔の残存 } \\
\text { 組織の損傷 }\end{array}$ \\
\hline
\end{tabular}

単独など) では Cefazorin (CEZ) $1 \mathrm{~g} /$ 回，口腔を開放する Class II の手術では Cefmetazole (CMZ) $1 \mathrm{~g} /$ 回, Sulbactam / Ampicillin (SBT/ABPC) 1.5 3 g/ 回, Flomoxef (FMOX) $1 \mathrm{~g} /$ 回などが推奖される。投与方法は静脈内投与とし，手術 開始時に十分な血中濃度が保たれるように手術 30 分前に投 与を開始し，手術が長時間にわたる場合には術中に追加投 与し閉創から少なくとも $2 \sim 3$ 時間後まで血中濃度が維持 されるように留意する必要がある。術中の投与間隔につい ては薬凨によって異なるが，打打よそ CEZで $3 \sim 4$ 時間， $\mathrm{CMZ}$ で 2 3 時間, SBT/ABPCで 2 3 時間, FMOXで 2 時間程度が推奨される。

\section{III. 手術部位感染 (SSI) の現状と 周術期口腔機能管理による新しい予防法}

上記のような予防策を講じても口腔がん手術後にSSIを 生じることがある (写真 1)、腔がんを含む頭頸部がん手

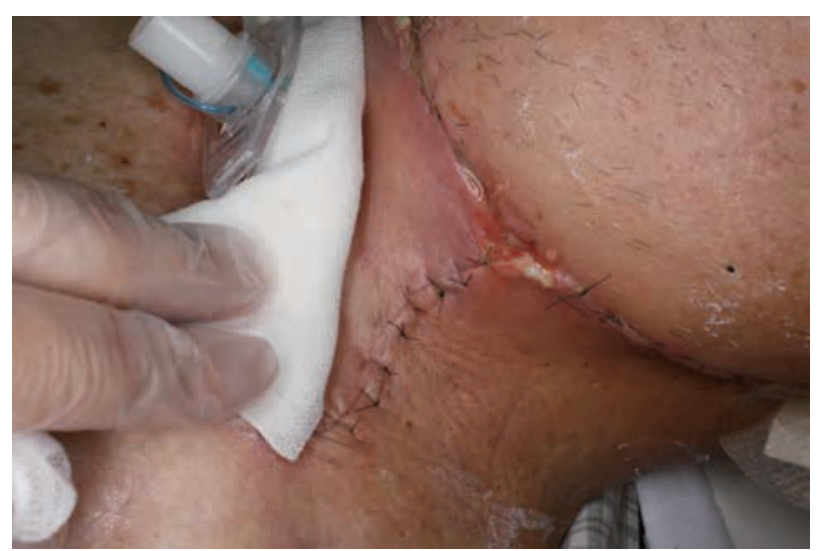

写真 1 口腔がん手術後 SSI

表 3 頭頸部がん術後 SSI の頻度

\begin{tabular}{|c|c|c|c|}
\hline 報告者 & 報告年 & SSI の頻度 & 対象 \\
\hline Ogihara & 2009 & $21 / 209(10.0 \%)$ & 頭頸部手術 \\
\hline Cunha & 2012 & $15 / 137(10.9 \%)$ & 頭頸部がん \\
\hline Lee & 2011 & $128 / 697(18.4 \%)$ & 頭頸部がん \\
\hline Cloke & 2004 & $21 / 100(21.0 \%)$ & 遊離皮弁再建 \\
\hline Coscun & 2004 & $60 / 207(29.0 \%)$ & 口腔と頸部が連続 \\
\hline Lofti & 2000 & $100 / 258(38.8 \%)$ & 口腔と頸部が連続 \\
\hline Karakida & 2010 & $112 / 276(40.6 \%)$ & 皮弁再建 \\
\hline Penel & 2005 & $117 / 260(45.0 \%)$ & 口腔と頸部が連続 \\
\hline
\end{tabular}

術後 SSI の頻度については，10４5\%程度とかなり高頻度 に生じることが報告されている（表 3） ${ }^{2 ２ ） ． と く に C l a s s ~}$ II の手術で皮弁再建を伴うような侵襲の大きな手術で SSI の頻度は高い，このことから，CDCのガイドラインを遵守 するのみでは口腔がん手術後 SSI を十分に予防することは できず，何らかの新たな対策が望まれていた。口腔がん手 術後 SSI の原因の 1 つに, 病原性微生物を含む口腔貯留液 に創部がさらされることが考えられるため，周術期の口腔 ケアにより口腔内の微生物を減少させることにより SSI を 䂆防しようとする試みがなされてきた。しかしこれまで口 腔ケアがSSI 予防に有効であるとするエビデンスレベルの 高い報告はない。

再建外科を伴う侵襲の大きな口腔がん手術では, 術後一 定期間気管切開下で管理されることが一般的である。回空 内に皮弁が移植され気管切開による挿管状態では，嚥下機 能の低下から口腔内の自浄作用は著しく損なわれる。われ われはICUに打ける挿管患者を用いた研究で, 挿管後口腔 


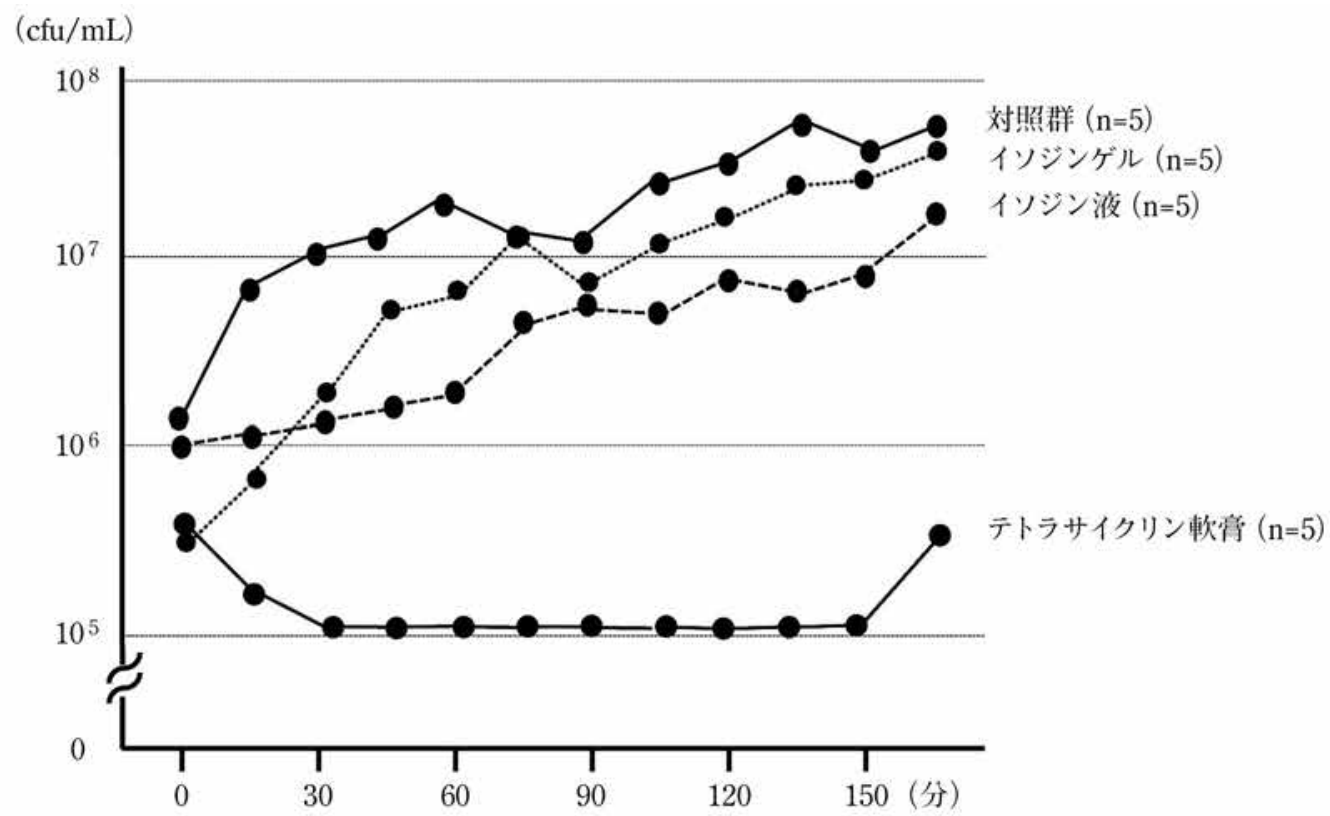

図 1 全身麻酔挿管患者における薬剤局所投与後の口腔咽頭貯留液中の細菌数推移 (文献 11 より引用, 一部改変)

咽頭貯留液中の細菌数は $10^{6} \mathrm{cfu} / \mathrm{mL}$ から $10^{8} \mathrm{cfu} / \mathrm{mL}$ と 100 倍以上に増加すること, ブラッシングや粘膜清拭では細菌 数は減少しないこと, $200 \mathrm{~mL}$ の水による口腔咽頭の洗浄 を行うと細菌数を挿管前のレベルにまで減少させることが できるが 3 時間経過すると再び 100 倍程度に増加すること を明らかにした ${ }^{10)}$ 。このことから口腔がん術後で挿管状 態の患者の口腔内細菌数を生理的な量に保つためには, 術 前のプラークフリー法は意味がなく, 術後に少なくとも 3 時間でとの口腔内洗浄が必要であると思われた。しかし短 時間で洗浄を繰り返すことは患者あるいは医療スタッフの 負担を考えると現実的ではない，沱こで消毒薬や抗菌薬の 局所投与により一定時間口腔内細菌の増殖を抑制できない かと考元, 全身麻酔挿管中患者の舌背に消毒薬や抗菌薬軟 膏を局所投与し口腔内細菌数の変化を調べたところ, イソ ジン液やイソジンゲルを舌背に塗布しても細菌数増殖は抑 制できなかったがテトラサイクリン軟膏 (アクロマイシン 軟膏 $\left.{ }^{\circledR}\right)$ を塗布すると細菌数増加を著明に抑制できたこと を報告した（図 1 $)^{11)}$ 。さらに頸部郭清，原発巣切除，皮 弁再建を行い気管切開下で管理された口腔がん術後患者で 検討を行ったところ, 通常の口腔ケアのみでは 3 時間後に 口腔咽頭貯留液中の細菌数は $10^{8} \mathrm{cfu} / \mathrm{mL}$ と健常者の 100 倍 以上に増加するが，テトラサイクリン軟高を舌背に塗布す ると, 約 6 時間の間は細菌数を $10^{6} \mathrm{cfu} / \mathrm{mL}$ 程度以下に抑制 できることを確認した（図 2)。テトラサイクリンを用いた のは古くから口腔外科領域で開放創に応用されており安全 性は確立していること，口腔がん術後 SSI の起炎菌である
ブドウ球菌や口腔レンサ球菌などに強い抗菌力を有するこ と，MRSAを誘導しにくいことなどが理由である。しかし 緑膿菌に対する抗菌力は強くなく, テトラサイクリンの局 所投与は漫然と長期間続けるべきではないと思われた。こ れらのことから，皮弁再建，気管切開を伴う口腔がん手術 では，SSI のリスクがとくに高いとされる術後 48 時間の間， テトラサイクリン軟膏を 6 時間ごとに舌背に塗布すること を口腔がん SSI に対する新たな䂆防法として提案した。本 法の SSI 予防に関する有効性を検証する目的で, 2015 年 4 月より 2 年間の予定で多施設共同ランダム化比較試験 (UMIN000018318）が開始されており，間もなく結果が明 らかになる予定である。

\section{N．術後肺炎と周術期口腔機能管理}

口腔がん手術後には嚥下機能障害から口腔内の自浄作用 が低下し口腔咽頭貯留液中の細菌数が著しく増加するとと もに，その污染された貯留を誤嚥することにより，術後肺 炎を発症することがある。口腔がん術後肺炎に関するエビ デンスレベルの高い論文がないため，比較的報告の多い食 道がん術後肺炎を参考に術後肺炎のリスクや予防法につい て検討してみることにする。

食道がん術後肺炎は打打よそ20～30\%程度に発症する。 そのリスク因子として，喫煙や呼吸機能低下，外科侵襲の 大きさ, 糖尿病などの合併症, 高齢などが知られているが, 口腔衛生状態との関連について多数例に基づいた報告はこ 


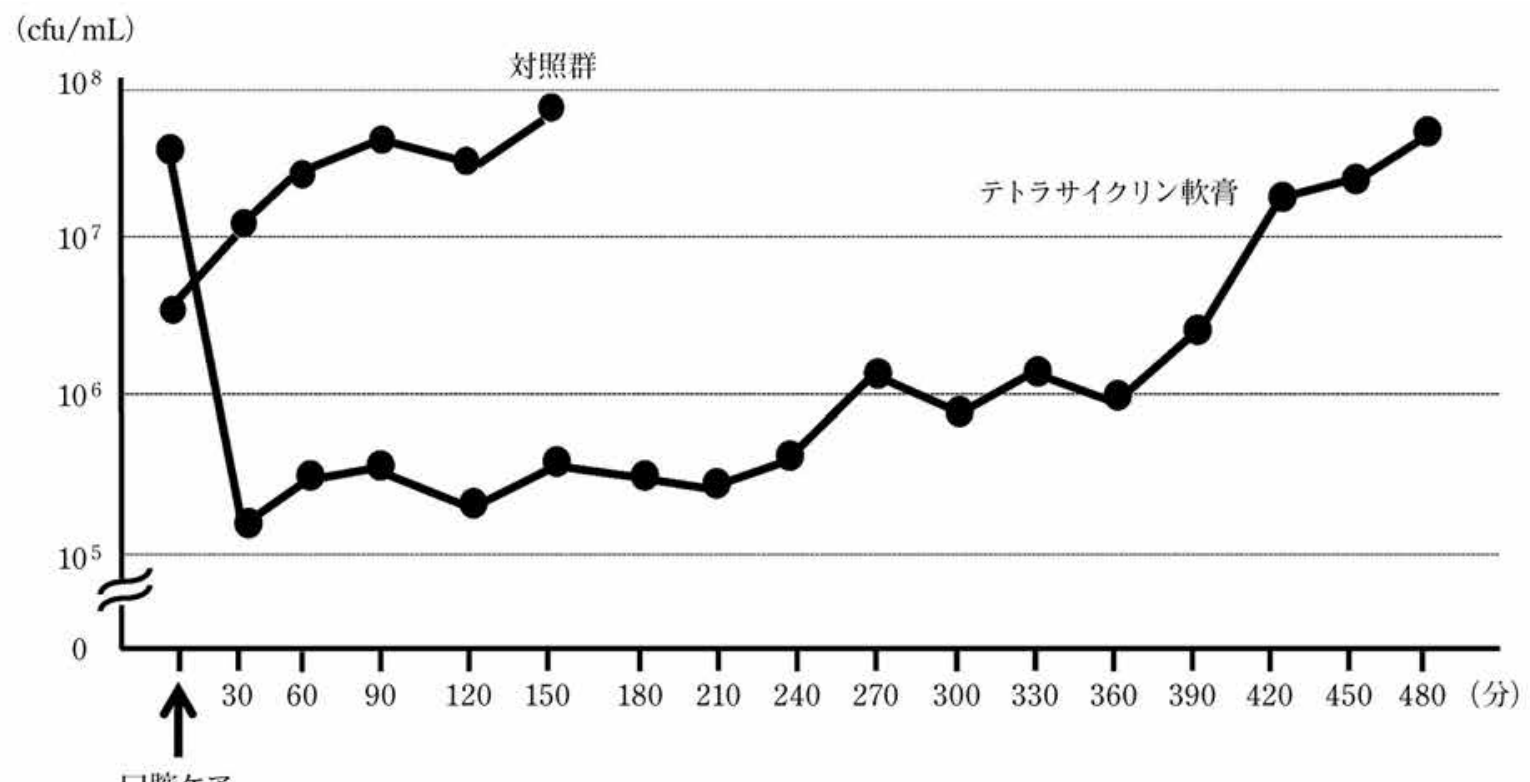

図 2 術後気管切開患者におけるテトラサイクリン局所投与後の口腔咽頭貯留液中の細菌数推移 (文献 11 より引用, 一部改变)

表 4 食道がん術後肺炎の頻度とリスク因子

\begin{tabular}{|c|c|c|c|c|}
\hline 報告者 & 報告年 & 患者数 & 術後肺炎発症率 & リスク因子 \\
\hline Yoshida & 2014 & 299 & 17.7 & 契煙, サルベージ手術, 出血量 \\
\hline Shiozaki & 2012 & 96 & 20.8 & 1 秒率, CRP, 喫煙 \\
\hline Bakhos & 2012 & 220 & 23.6 & 年齢, 幽門側ドレナージ非施行 \\
\hline Sunpaweravong & 2012 & 232 & 22.8 & 燕下障害, 1 秒率, 手術方法, 手術時間 \\
\hline Paul & 2011 & 112 & 13.4 & 呼吸器合併症, 喫煙, 1 秒率, 吸入酸素濃度, 周術期強心剂使用 \\
\hline Furguson & 2011 & 516 & 38.2 & 年齢, 1 秒率, DLCO \%, PS, クレアチニン, 喫煙, 開胸 \\
\hline Zingg & 2011 & 858 & 27.4 & 喫煙, 合併症の数 \\
\hline Dhungel & 2010 & 1,032 & 27 & 糖尿病, 喫煙, 飲酒, 手術時間 \\
\hline Nakamura & 2008 & 184 & 19.6 & ステロイド非使用, 出血量, 呼吸リ八非施行 \\
\hline Jiao & 2006 & 358 & 12 & 1 秒率 \\
\hline Kinugasa & 2005 & 118 & 50 & 年齢, 喫煙, 呼吸機能低下 \\
\hline Law & 2003 & 421 & 15.6 & 年齢, 手術時間, 腫瘍の部位 \\
\hline Fang & 2003 & 441 & 7.3 & 大手術の既往, 肺機能障害, 腎障害, 年齢 \\
\hline Avedano & 2002 & 61 & 36.1 & 1 秒率, 年齢, 化学放射線療法 \\
\hline Ferguson & 2002 & 292 & 26.7 & 喫煙, 1 秒率, 糖尿病, 年齢, PS, 手術方法 \\
\hline
\end{tabular}

れまでなかった（表 4) 12 26)，周術期の口腔ケアにより術 後肺炎の発症を抑制したとする報告が本邦ではいくつかあ るが 27〜30), いずれも単施設の少数例に基づいた報告で, 群間のバイアスや交絡の存在などの面からみてもエビデン
スレベルの高い論文はない，われわれは多施設共同後ろ向 き観察研究において, 周術期の口腔ケアは食道がん術後肺 炎の発症頻度を低下させることを初めて明らかにした ${ }^{31)}$. しかしそのデータを詳細に検討すると, 術後嚥下障害を生 
じなかった患者においては周術期の口腔ケアは食道がん術 後肺炎の発症率を有意に低下させたが，術後嚥下障害をき たした患者においては周術期の口腔ケア施行の有無にかか わらず高率に術後肺炎が発症しており，機械的な口腔ケア のみでは術後嚥下障害をきたした患者では術後肺炎予防に は不十分であることが示唆された。腔がん手術に打いて も外科侵襲の大きな手術や術後嚥下障害をきたす場合, 術 後気管切開による挿管下で管理される場合などでは, 食道 がん手術と同様，術後肺炎予防が大きな問題となる．今後， 十分な全身的抗菌薬療法とともに, 術後肺炎予防に有効な 口腔管理方法の確立が課題である。

\section{V. 結 語}

口腔がん手術後にSSI や肺炎を発症すると, 患者の Quality of life 低下だけではなく, 再発高リスク例においては後続 治療の遅れから, 生命予後にまで影響を及ぼす. CDC ガイ ドラインなどに代表される術後感染全般に対する理解と正 しい感染予防対策を講じることは必須であるが，それにも かかわらず術後感染を十分には予防できていないのが現状 である。 2012 年に診療報酬に導入された周術期口腔機能 管理は，がん治療時の合併症の予防を目的とするものであ るが，口腔ケア方法の確立や有効性に関するエビデンス検 証は今後の課題である。今回紹介した術後 48 時間の間テ トラサイクリン軟膏を舌背部に 6 時間ごとに塗布する方法 は, 口腔内の細菌数を生理的な量に抑制できることが示さ れており, SSI 予防に有効であることが期待され, 現在進 行中の多施設共同前向き研究の結果が待たれる.

本論文に関して，開示すべき利益相反状態はない.

\section{引用文献}

1) Mangram AJ, Horan TC, et al: Guideline for Prevention of Surgical Site Infection, 1999. Centers for Disease Control and Prevention (CDC) Hospital Infection Control Practices Advisory Committee. Am J Infect Control 27: 97-132, 1999.

2 ) Ogihara H, Takeuchi K, et al : Risk factors of postoperative infection in head and neck surgery. Auris Nasus Larynx 36: 457-460, 2009.

3 ) Cunha TFS, Melancia TAS, et al : Risk factors for surgical site infection in cervico-facial oncological surgery. J Cranio-Maxillo-Fac Surg 40: 443-448, 2012.

4 ) Lee DH, Kim SY, et al : Risk factors of surgical site infection in patients undergoing major oncological surgery for head and neck cancer. Oral Oncol 47: 528-531, 2011.

5 ) Cloke DJ, Green JE, et al : Factors influencing the development of wound infection following fee-flap reconstruction for intra-oral cancer. Br J Plast Surg 57: 556-560, 2004.

6 ) Coskun H, Erisen L, et al : Factors affecting wound infection rates in head and neck surgery. Otolaryngol-Head Neck Surg 123: 328-333, 2000.

7 ) Lotfi CJ, Cavalcanti Rde C, et al : Risk factors for surgical-site infections in head and neck cancer surgery. Otolaryngol Head Neck Surg 138: 74-80, 2008.

8 ) Karakida K, Aoki T, et al : Analysis of risk factors for surgical-site infections in 276 oral cancer surgeries with microvascular free-flap reconstructions at a single university hospital. J Infect Chemother 16 : 334-339, 2010.

9 ) Penel N, Fournier C, et al : Multivariate analysis of risk factors for wound infection in head and neck squamous cell carcinoma surgery with opening of mucosa. Study of 260 surgical procedures. Oral Oncol 41: 294-303, 2005.

10) Hayashida S, Funahara M, et al : The effect of tooth brushing, irrigation, and topical tetracycline administration on the reduction of oral bacteria in mechanically ventilated patients: a preliminary study. BMC Oral Health 16: 67, 2016.

11) Funahara M, Hayashida $S$, et al : Efficacy of topical antibiotic administration on the inhibition of perioperative oral bacterial growth in oral cancer patients: a preliminary study. Int J Oral Maxillofac Surg 44: 1225-1230, 2015.

12) Yoshida N, Watanabe M, et al : Risk factors for pulmonary complications after esophagectomy for esophageal cancer. Surg Today 44: 526-532, 2014.

13) Shiozaki A, Fujiwara $H$, et al : Risk factors for postoperative respiratory complications following esophageal cancer resection. Oncol Lett 3: 907-912, 2012.

14) Bakhos CT, Fabian $T$, et al : Impact of the surgical technique on pulmonary morbidity after esophagectomy. Ann Thorac Surg 93: 221-226, 2012.

15) Sunpaweravong S, Ruangsin S, et al : Prediction of major postoperative complications and survival for locally advanced esophageal carcinoma patients. Asian J Surg 35: 104-109, 2012.

16) Paul DJ, Jamieson GG, et al : Perioperative risk analysis for acute respiratory distress syndrome after elective oesophagectomy. ANZ J Surg 81: 700-706, 2011.

17) Ferguson MK, Celauro $\mathrm{AD}$, et al : Prediction of major pulmonary complications after esophagectomy. Ann Thorac Surg 91: 1494-1500, 2011.

18) Zingg U, Smithers BM, et al : Factors associated with postoperative pulmonary morbidity after esophagectomy for cancer. Ann Surg Oncol 18: 1460-1468, 2011.

19) Dhungel B, Diggs BS, et al : Patient and peri-operative predictors of morbidity and mortality after esophagectomy: American College of Surgeons National Surgical Quality Improvement Program (ACS-NSQIP), 
2005-2008. J Gastrointest Surg 14: 1492-1501, 2010.

20) Nakamura M, Iwahashi $M$, et al : An analysis of the factors contributing to a reduction in the incidence of pulmonary complications following an esophagectomy for esophageal cancer. Langenbecks Arch Surg 393: 127-133, 2008.

21) Jiao WJ, Wang TY, et al : Pulmonary complications in patients with chronic obstructive pulmonary disease following transthoracic esophagectomy. World J Gastroenterol 12: 2505-2509, 2006.

22) Kinugasa S, Tachibana M, et al : Postoperative pulmonary complications are associated with worse shortand long-term outcomes after extended esophagectomy. J Surg Oncol 88: 71-77, 2004.

23) Law S, Wong K, et al : Predictive factors for postoperative pulmonary complications and mortality after esophagectomy for cancer. Ann Surg 240: 791-800, 2004.

24) Fang W, Kato H, et al : Analysis of pulmonary complications after three-field lymph node dissection for esophageal cancer. Ann Thorac Surg 76: 903-908, 2003.

25) Avendano CE, Flume PA, et al : Pulmonary complica- tions after esophagectomy. Ann Thorac Surg 73: 922926, 2002.

26) Ferguson MK and Durkin AE : Preoperative prediction of the risk of pulmonary complications after esophagectomy for cancer. J Thorac Cardiovasc Surg 123: 661-669, 2002.

27) Akutsu Y, Matsubara H, et al : Pre-operative dental brushing can reduce the risk of postoperative pneumonia in esophageal cancer patients. Surgery 147: 497-502, 2010.

28）岸本裕充, 野口一馬, 他: 食道癌手術患者の周術期 口腔管理による術後肺炎予防. 口腔感染症学会雑誌 13: 25-28, 2006.

29）森川知昭, 木崎久美子, 他：手術直前に実施したプ ラークフリー法による食道癌術後肺炎予防の有効 性. 日衛学誌 2: 43-47, 2008.

30）足立忠文, 三木仁美, 他：食道癌周術期における術 後肺炎に対する口腔ヶアの効用について。 日摂食嚥 下リ八会誌 12: 40-48, 2008.

31) Soutome S, Yanamoto S, et al : Preventive effect on post-operative pneumonia of oral health care among patients who undergo esophageal resection: A multicenter retrospective study. Surg Infect, 2016, in press. 